\title{
PALEOMAGNETISM OF SOME SEDIMENTARY ROCKS OF THE LATE PALEOZOIC TUBARÃO AND PASSA DOIS GROUPS, FROM THE PARANA BASIN, BRAZIL
}

\author{
DANIEL A. VALENCIO*, A. G. ROCHA-GAMPOS**, and I. G. PACCA***
}

\begin{abstract}
The after thermic cleaning magnetic remanence directions of twelve hand samples collected at different stratigraphic positions from the Itararé Subgroup (Tubarão Group) exposures at the Mococa area give a palcomagnetic pole at $57^{\circ}$ South, $357^{\circ}$ East, $\alpha_{95}=15^{\circ}$. The position of this pole is close to other South American paleomagnetic poles assigned to the Upper Carboniferous suggesting an equivalent age for the Itararé redbeds from Mococa. The cleaned magnetic remanences of seventeen hand samples collected at different stratigraphic positions of the Corumbatai Formation exposures (Passa Dois Group) in the Artemis-Piracicaba area define three reversals of the geomagnetic field. On the basis of the geological data and the present knowledge about the Late Paleozoic Interval of Reversed Geomagnetic Polarity, those changes of polarity are interpreted as evidence of an Upper Tartarian age for the Corumbatai redbeds from the Artemis-Piracicaba area. On the assumption of a geocentric dipole the paleomagnetic pole for the Corumbataí redbeds is calculated at $86^{\circ}$ South, $294^{\circ}$ East, $\alpha_{95}=14^{\circ}$. This pole would define a "time group" with the other Middle and Upper Permian paleomagnetic poles for South America.
\end{abstract}

RESUMO Determinações, após lavagem térmica, das direçð̃es do magnetismo remanescente de doze amostras de superfície, coletadas em diferentes niveis do Subgrupo tararé (Grupo Tubarão), na área de Mococa, Estado de São Paulo, forneceram um polo paleomagnético localizado a $57^{\circ} \mathrm{S}$, $357^{\circ} \mathrm{E}, \alpha_{95}=15^{\circ}$. A posição deste pólo é próxima da de outros pólos paleomagnéticos sul-americanos atribuídos ao Carbonífero Superior, o que sugere uma idade equivalente para os sedimentos analisados. Determinaçóes semelhantes realizadas em dezessete amostras de superficie, coletadas em diferentes níveis de Formação Corumbataí (Grupo Passa Dois), na região de Artemis-Piracicaba, Estado de São Paulo, permitiram definir très reversões do campo magnético. Com base nos dados geológicos disponíveis e nas características do Intervalo Neopaleozóico de Polaridade Geomagnética Reversa, interpretam-se as mudanças de polaridade como evidéncia da idade neotartariana para os sedimentos estudados da Formaçăo Corumbataí. O pólo geomagnético correspondente localiza-se a $86^{\circ} \mathrm{S}, 294^{\circ} \mathrm{E}, \alpha_{95}=14^{\circ}$, formando um "grupo de tempo" com outros pólos paleomagnéticos meso e neopermianos da América do Sul.

INTRODUCTION The present knowledge about the Late Paleozoic reversals of the geomagnetic field (Valencio and Mitchell, 1972), generally known as the Kiaman Magnetic Interval or Late Paleozoic Interval of Reversed Geomagnetic Polarity, allow us to assign an age according with the polarity of their primary magnetic remanences to those rocks formed within the interval Upper Carboniferous-Lower Triassic. Obviously, this is only valid for those rocks whose Upper Paleozoic-Lower Mesozoic ages are supported by classical geological (paleontology, paleobotany, stratigraphy, etc.) data and holders of magnetic remanences originated during their formation.

*Departamento de Ciencias Geológicas, Facultad de Ciencias Exactas y Naturales, Universidad de Buenos Aires, Ciudad Universitaria, Pabellon 2, Buenos Aires, Argentina

**Instituto de Geociências, Universidade de São Paulo, Cidade Universitária, Caixa postal 20899, São Paulo, Brasil

***Instituto A stronômico e Geofisico, Universidade de São Paulo, Caixa Postal 30627, São Paulo, Brasil 
Exposures of Late Paleozoic redbeds of the Corumbataí Formation (Passa Dois Group) and the Itararé Subgroup (Tubarão Group) are present in the São Paulo and Minas Gerais States, Brazil. A preliminary collection of hand samples of these groups was carried out by the authors in May of 1971. The significance of the polarity of the cleaned magnetic remanence of these samples on the age of the Corumbataí Formation and the Itararé Subgroup on the basis of the Late Paleozoic Interval of Reversed Geomagnetic Polarity, has been briefly discussed in a previous paper (Valencio, 1972). In this paper the details on results obtained in the paleomagnetic study of these samples are given. A discussion about the significance of the polar positions computed for the Corumbatai Formation and the Itararé Subgroup in relation with their more probable ages is also given.

GEOLOGICAL EVIDENCE Fig. 1 shows the location of samples collected from the Tubarão Group (Itararé Subgroup) and Corumbataí Formation (Passa Dois Group) in the States of São Paulo and Minas Gerais.

Relative stratigraphic position of rocks collected from the Itararé Subgroup (Rocha-Campos, 1967) in the Mococa-Casa Branca area was preliminarily established during field work and through comparison with the schematic section prepared by Figueiredo and Frakes (1968).

The section sampled runs only slightly oblique to regional strike of strata, thus making difficult an accurate measurement of a stratigraphic section. On basis of available geological information the samples seem to represent different horizons within the Itarare, although the total thickness involved is presently unknown.

The Itararé sequence in the northeastern extremity of the Paraná Basin differs in

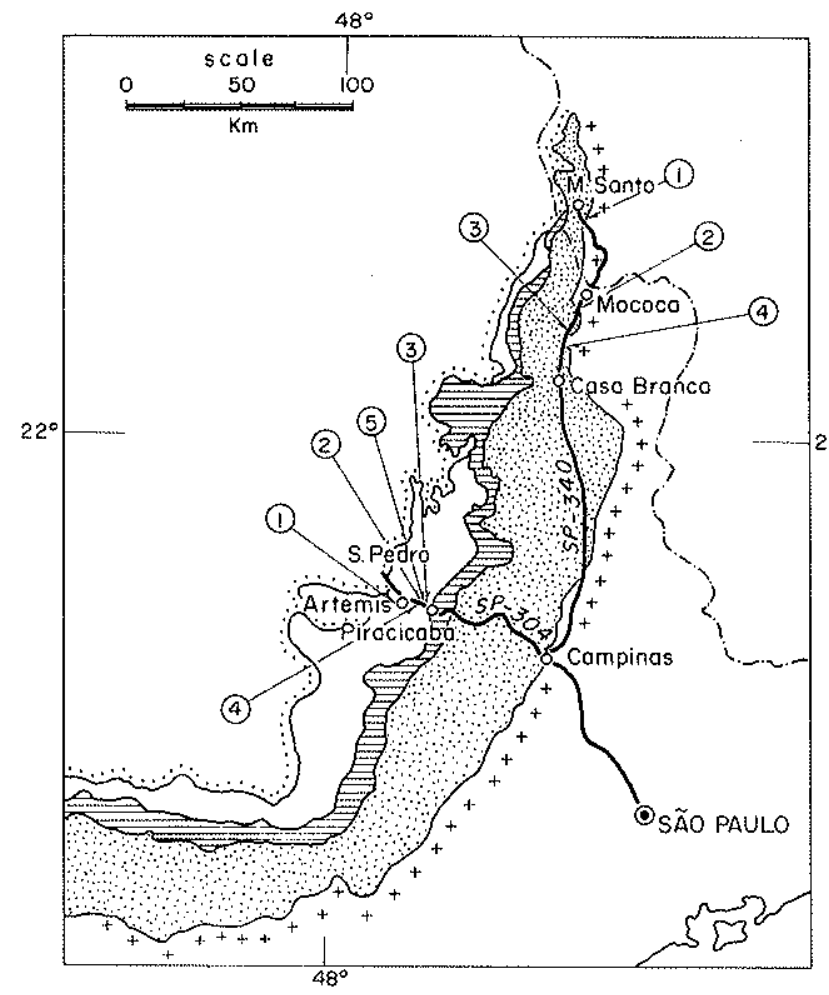

Figure 1 - Schematic geological map and sampling sites of the Corumbatai Formation (Passa Dois Group) and the Itararé Subgroup (Tubarão Group), Pa$2^{\circ}$ raná Basin, Brazil. Explanation: crosses: Precambrian basement; dots: Itararé Subgroup; horizontal hatched: Tatú Formation; blanck: Passa Dois Group; west of dotted line: Mesozoic and Cenozoic cover. SP-304, 1: Rio Piracicaba near Artemis; 2: km 176,5;3: km 178,8; 4: $\mathrm{km} \mathrm{179;5:} \mathrm{km} \mathrm{179,7.} \mathrm{SP-340,} \mathrm{1:}$ near Monte Santo; 2: km 261,4;3: km 243,$8 ; 4: \mathrm{km} \mathrm{249,6}$ 
some aspects from the southern section including with respect to facies (Figiueiredo and Frakes, 1968) and the red color of diamictites and associated sediments.

In view of the lack of systematic mapping and regional detailed stratigraphic work (now under way) the correlation of the red glacial sequence of northern São Paulo and southern Minas Gerais with the Itararé Subgroup-Aquidauana Group sequence (Rocha-Campos, 1967) is still under debate.

On basis of gross lithological similarity (and possibly the color) this sequence has been correlated by Almeida (1954) with the Aquidauana "Series" of Mato Grosso and Goiás. It was also considered as younger than the uppermost diamictite of the Itarare in the typical area of central and southern São Paulo (Almeida, 1954), possibly partially contemporaneous to the post-glacial sequence (Tatuí Formation, Rocha-Campos, 1967).

Other authors, however (Landim, 1970), indicate an interfingering relationship between the Itararé of northern São Paulo and the typical sequence further south.

On basis of preliminary palynological zonation the glacial sequence of the Parana Basin (Itararé + Aquidauana) was assigned by Daemon and Quadros (1970) an age varying from Upper Carboniferous (Stephanian G) to "Upper" Permian (Kungurian). The Aquidauana was considered mostly Upper Carboniferous.

This time span for the glaciation in the Paraná Basin is presently in partial disagreement with other paleontological information based on megaplants and invertebrates (Rocha-Campos, 1973) and other palynological studies (Kemp, 1973). The approximate age interpretations derived from the distribution of megaplants and marine invertebrates would suggest a general Lower Permian (Sakmarian?) or perhaps older age for the uppermost part of the glacial sequence (Rocha-Campos, 1973). Kemp (1973) recognized in the Itararé assemblages comparable with Microflores 1-3 of the Australian zonal scheme (Evans, 1967), which could also indicate an age ranging from Upper Carboniferous to Lower Permian for the Itararé, an assignement not in conflict with the data derived from marine invertebrates and megaplants.

Stratigraphic position of samples from the Corumbatai Formation collected along the Piracicaba-Artemis road could be more accurately determined.

They cover about 150 meters of the total thickness of the Corumbatai Formation outcropping in the region, but are irregularly distributed along the section.

The stratigraphic succession of the samples was interpreted taking into account a regional dip of the strata of the order of $0.5^{\circ}$ which is considered as adequate for the area (Table I).

Palynological information from strata considered as equivalent to the Corumbatai Formation in the southern part of Paraná Basin indicates an age at least as young as Kazanian (Daemon and Quadros, 1970). The recent finding of the reptile Endothiodon in sediments of the Rio do Rasto Formation which concordantly overlies the Estrada Nova Formation (= Corumbataí Formation) in Paraná State (Barberena, 1973 personal communication) indicates an Upper Permian age for the Rio do Rasto.

On basis of the available information the age of the Corumbatai sediments may thus vary from Kazanian to possibly Tartarian.

THE PALEOMAGNETIC STUDY A preliminary sampling of the Passa Dois and Tubarão Groups was carried out in 1971 on the basis of the geological studies mentioned above. Twenty four oriented hand samples of redbeds from the Corumbatai Formation of the Passa Dois Group and fourteen hand samples of redbeds from the Itarare Subgroup of the Tubarão Group were collected in the São Paulo and Minas Gerais sections of the Paraná Basin. The orientation of hand samples was carried out when possible using both 
Table I - Summary of the palaeomagnetic data of the Corumbataí Formation (Tubarão Group) and the Itararé Subgroup (Passa Dois Group), from the Paraná Basin, Brasil

\begin{tabular}{|c|c|c|c|c|c|c|c|c|c|c|c|c|c|c|c|c|c|}
\hline \multirow{4}{*}{ Group } & \multirow{4}{*}{$\begin{array}{l}\text { Formation } \\
\text { or } \\
\text { Sulgroup }\end{array}$} & \multirow{2}{*}{\multicolumn{2}{|c|}{ Site }} & \multirow{2}{*}{\multicolumn{2}{|c|}{$\begin{array}{c}\text { Stratigraphic } \\
\text { level }\end{array}$}} & \multirow[b]{2}{*}{$\begin{array}{l}\text { Surple } \\
\text { number }\end{array}$} & \multicolumn{4}{|c|}{ Di rections of cleaned n.r.m. } & \multirow[b]{2}{*}{ Polarity } & \multirow{2}{*}{$\begin{array}{c}\text { Curie } \\
\text { Point } \\
{ }^{\circ} \mathrm{C}\end{array}$} & \multicolumn{5}{|c|}{ Virtual geomagnetic poles } \\
\hline & & & & & & & $\begin{array}{l}\text { number } \\
\text { of } \\
\text { disks }\end{array}$ & $D^{(0)}$ & $I^{(c)}$ & $95^{(0)}$ & & & $\begin{array}{l}\text { Lat (o) } \\
\text { South }\end{array}$ & $\begin{array}{c}\text { Long(o) } \\
\text { East }\end{array}$ & $d \psi^{(0)}$ & ${ }_{095}^{(0)}$ & $d x^{[0]}$ \\
\hline & & Highway & $304 ; \mathrm{Km} 178.8$ & High & Section & 35 & 3 & 218 & 45 & 27 & $\mathbf{R}$ & 650 & 56 & 238 & 21 & & 34 \\
\hline & & Highway & $304: \mathrm{Km} 178.8$ & High & Section & $1^{34}$ & 3 & 138 & 55 & B & $\mathrm{R}$ & 650 & 51 & 13 & 6 & & \\
\hline $\mathbf{p}$ & $\mathrm{c}$ & Hightway & $304 ; \mathrm{Km} 178.8$ & High & Section & 33 & 3 & 148 & 44 & 12 & $\mathbf{R}$ & 650 & 61 & 29 & 10 & & 15 \\
\hline A & 0 & Highway & $304:$ Kn 178.8 & High & Section & 32 & 3 & 149 & 59 & 11 & $\mathbf{R}$ & 650 & 58 & 1 & 13 & & 17 \\
\hline s & $\mathbf{R}$ & Highway & $304 ; \mathrm{kin} 178.8$ & High & Section & 31 & 1 & 119 & 62 & $=$ & $\mathbf{R}$ & 650 & 36 & 5 & - & & \\
\hline s & $u$ & Highway & $304 ; \mathrm{Km} 178.8$ & High & Section & 37 & 2 & 118 & 29 & 74 & R & $650 ?$ & 51 & 37 & 45 & & \\
\hline A & M & Highway & $304 ; \mathrm{Krin} 179.7$ & Middle & Section & 40 & 3 & 10 & -22 & 11 & x? & $150 / ?$ & 76 & 175 & 6 & & 12 \\
\hline & B & Hi ghway & $304 ; \mathrm{Km} \quad 179.7$ & Middle & Section & 39 & 6 & 26 & -27 & 15 & N & $200 / 600$ & 64 & 210 & 9 & & 17 \\
\hline$D$ & A & Highway & $304: \mathrm{Ks} 179.7$ & Middle & Section & 38 & 2 & 29 & -28 & 14 & к? & $?$ & 61 & 213 & 9 & & 17 \\
\hline 0 & $\mathrm{~T}$ & Hi ghway & $304 ; \mathrm{Km}_{\mathrm{m}} 176.5$ & Loliet & Section & 29 & 2 & 355 & -31 & 16 & N & $>300$ & 83 & 92 & 10 & & 18 \\
\hline t & A & Highway & $304 ; \operatorname{Knm} 176.5$ & Lonet & Section & 30 & 3 & 316 & -43 & 55 & $x$ & $200 />300$ & 49 & 29 & 42 & & 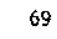 \\
\hline$s$ & 1 & Highway & $304 ; \mathrm{Km} 179$ & Lower & Section & 56 & 4 & $3+8$ & -35 & 8 & $x$ & 600 & 79 & 53 & 8 & & 4 \\
\hline & & Highway & $304:$ Kn 179 & Loner & Section & 55 & 3 & 284 & 31 & 7 & $\mathbf{R}$ & 600 & 30 & 231 & 4 & & 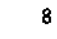 \\
\hline & & Hi ghtway & $304 ; \operatorname{Ktan} 179$ & Lower & Section & 54 & 3 & 355 & $-\$ 0$ & 3 & $\mathrm{~s}$ & 600 & 85 & 33 & 2 & & \\
\hline & & Highway & $304 ;$ Km 179 & Lower & Section & 53 & 2 & 4 & -47 & 16 & $\mathrm{~N}$ & $<200$ & 83 & 283 & 11 & & 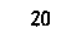 \\
\hline & & Piracical & River & Lower & Section & 52 & 2 & 351 & -14 & 29 & $\mathrm{~N}$ & 3 & 81 & 17 & 22 & & 36 \\
\hline & & pi racical & aba River & Loher & Section & 51 & 2 & 20 & -37 & 17 & $\mathbf{N}$ & 600 & 71 & 222 & 12 & & \\
\hline & & SAP10 & & $15 \operatorname{tmi}$ & & & - & - & - & $\cdot \cdot$ & - & & 86 & 294 & & 14 & \\
\hline & & Highway & $340 ; \mathrm{Kn} 249.6$ & High $S$ & ection & $2 \mathbf{i}$ & 2 & 350 & 56 & 15 & $\mathrm{R}$ & $>300$ & 60 & 7 & 24 & & \\
\hline & & Highway & $340 ; \mathrm{Km} 249.6$ & Hìgh $S$ & ection: & 20 & 3 & 165 & 42 & 37 & $\mathbf{R}$ & 650 & 36 & 32 & 28 & & \\
\hline & & Hightway & $340 ; \operatorname{Km} 249.6$ & High S & ection: & 18 & 2 & 150 & 35 & 47 & $\mathbf{R}$ & $>300$ & 62 & 44 & 31 & & \\
\hline$T$ & $I$ & Highway & $340 ; K \pi \quad 243.8$ & Middle & Section & 8 & 4. & 124 & 57 & 9 & R & 650 & 40 & 12 & 10 & & 14 \\
\hline $\mathrm{U}$ & $\mathrm{T}$ & Highway & $340 ; \operatorname{kin} 243.8$ & Middle & Section & 7 & 4 & 244 & 70 & 7 & $\mathbf{R}$ & 650 & 33 & 274 & 10 & & 12 \\
\hline B & A & Highway & $340 ;$ Kat 243.8 & Middle & Section & 9 & 3 & 134 & 60 & 2 & $\mathrm{R}$ & 650 & 47 & 6 & 2 & & 3 \\
\hline A & 8 & Highway & $340 ; \dot{K}=261.4$ & Basal : & Section & $f^{13}$ & 3 & 146 & 50 & 10 & R & 650 & 59 & 20 & 9 & & 3 \\
\hline $\mathrm{R}$ & A & Higłway & $340 ; \mathrm{Km} 261.4$ & Basal : & Section & 11 & 3 & 144 & 70 & 10 & R & 650 & 50 & 347 & 9 & & \\
\hline A & $R$ & Highway & $340 ; \mathrm{Km} 261.4$ & Basal & Section & 14 & 3 & 119 & 58 & in & $\mathbf{R}$ & 650 & 36 & 10 & 13 & & 17 \\
\hline 0 & $\mathbf{E}$ & Highway & $340 ; \mathrm{Km} 261,4$ & Basal & Section & $t_{12}$ & 2 & 171 & is & 19 & $\mathbf{R}$ & 650 & 55 & 322 & 30 & & 14 \\
\hline & & $\begin{array}{l}\text { Nococa-M } \\
\text { road }\end{array}$ & binte Santo & Basal & Section & 17 & 2 & 100 & 65 & 27. & R & $>300$ & 22 & 359 & 35 & & \\
\hline & & $\begin{array}{l}\text { Mococa-M } \\
\text { road }\end{array}$ & tonte Santo & Rasal s & Section & 16 & 2 & 173 & 45 & 17 & $\mathbf{R}$ & $>200$ & 83 & 4 & 14 & & \\
\hline & & SACB & & All the & ie units & 12 & - & - & - & - & - & & 57 & 357 & & 10 & \\
\hline
\end{tabular}


sun and magnetic compasses. In most cases magnetic azimuths agree with sun-compass azimuths within $\pm 4^{\circ}$ and the mean of the magnetic and sun compasses was used. Whenever disagreement exceeded $4^{\circ}$ the sun-compass azimuths were used. Samples of the Corumbataí Formation were collected at differente stratigraphic positions along the highway SP-304 between Piracicaba-Artemis, São Paulo State (Fig. 1); however, they do not represent a continuous stratigraphic section.

Hand samples of the Itararé Subgroup were collected also at different stratigraphic levels, along the highway SP-340, between Casa Branca and Mococa (São Paulo State) and the dust road between Mococa and Monte Santo de Minas (Minas Gerais State) (Fig. 1), but they do not cover a continuous stratigraphic section of the Itarare sediments.

After being returned from the field, the hand samples were cut into cylinders $2.5 \mathrm{~cm}$ in diameter and one centimeter in length in the Paleomagnetic Laboratory of the University of São Paulo. A spinner magnetometer was used to measure the natural remanent magnetization of these cylinders (Figs. 2a and 4a). During the measurements many disks broke due to the high number of revolutions of the magnetometer. Detailed thermal cleaning was used to determine the stability of the remanent magnetization. One cylinder from each sample was subjected to thermal cleaning in steps of $100^{\circ} \mathrm{C}$ to $650^{\circ} \mathrm{C}$. In this way the best temperature isolating the stable remanent magnetization of each sample was determined. The criterion adopted for the choice of the best temperature was that the direction of the remanence of the pilot cylinder exhibited no further change in response to treatments at higher temperatures. A second and sometimes more cylinders of the same hand sample were submited to this best temperature for a better definition of the direction of the stable remanent magnetization of the sample.

Fisher's statistics (1953) was used to compute the mean direction of the stable remanence of each sample on the basis of the direction of the cleaned remanent magnetization of its cylinders (Figs. $2 \mathrm{~b}$ and $3 \mathrm{~b}$ ).

GORUMBATAI FORMATION The mean directions of the natural remanent mag. netization of each hand sample from the Corumbataí Formation are shown in Fig. 2 a. Seven of these hand samples have reversed stable remanence (Fig. 2b). Directions of the natural remanent magnetization of samples with normal stable remanence are fairly well grouped, but those of samples with reversed stable remanence are highly scattered (Figs. $2 a$ and $2 b$ ). Thermal demagnetization curves of representative samples from the Corumbatai Formation are shown in Fig. 3. It can be seen by the shapes of the demagnetization curves that a wide spectrum of blocking temperatures is represented. Particularly, most of the samples with stable remanence of normal polarity shows a continuous range of blocking temperatures. The samples with reversed stable remanence have blocking temperatures ranging from $600^{\circ} \mathrm{C}$ to $675^{\circ} \mathrm{C}$; the shape of the demagnetization curves of these samples suggests that a secondary remanence oriented in the direction of a normal polarity field has been destroyed after the partial demagnetization at $300^{\circ} \mathrm{C}$. The best demagnetizing temperature for the samples from the Corumbataí Formation is at about $300^{\circ} \mathrm{C}$. Most of these samples keep more than 0.5 of their natural remanent magnetization $(\mathrm{Jr} / \mathrm{Jo} \geq 0.5)$ after the thermal demagnetization at $300^{\circ} \mathrm{C}$.

Directions of the stable remanence of samples from the Corumbatai Formation are reasonably well grouped (Fig. 2b). Particularly, directions of the samples with reversed stable remanence are substantially better grouped after thermal cleaning than before.

The mean directions of magnetization for each sample after thermal cleaning and bedding plane correction are given in Table $\mathrm{I}$ and plotted in Fig. 2b. Seven of the samples yield mean directions toward the south with positive inclinations. These samples are re- 

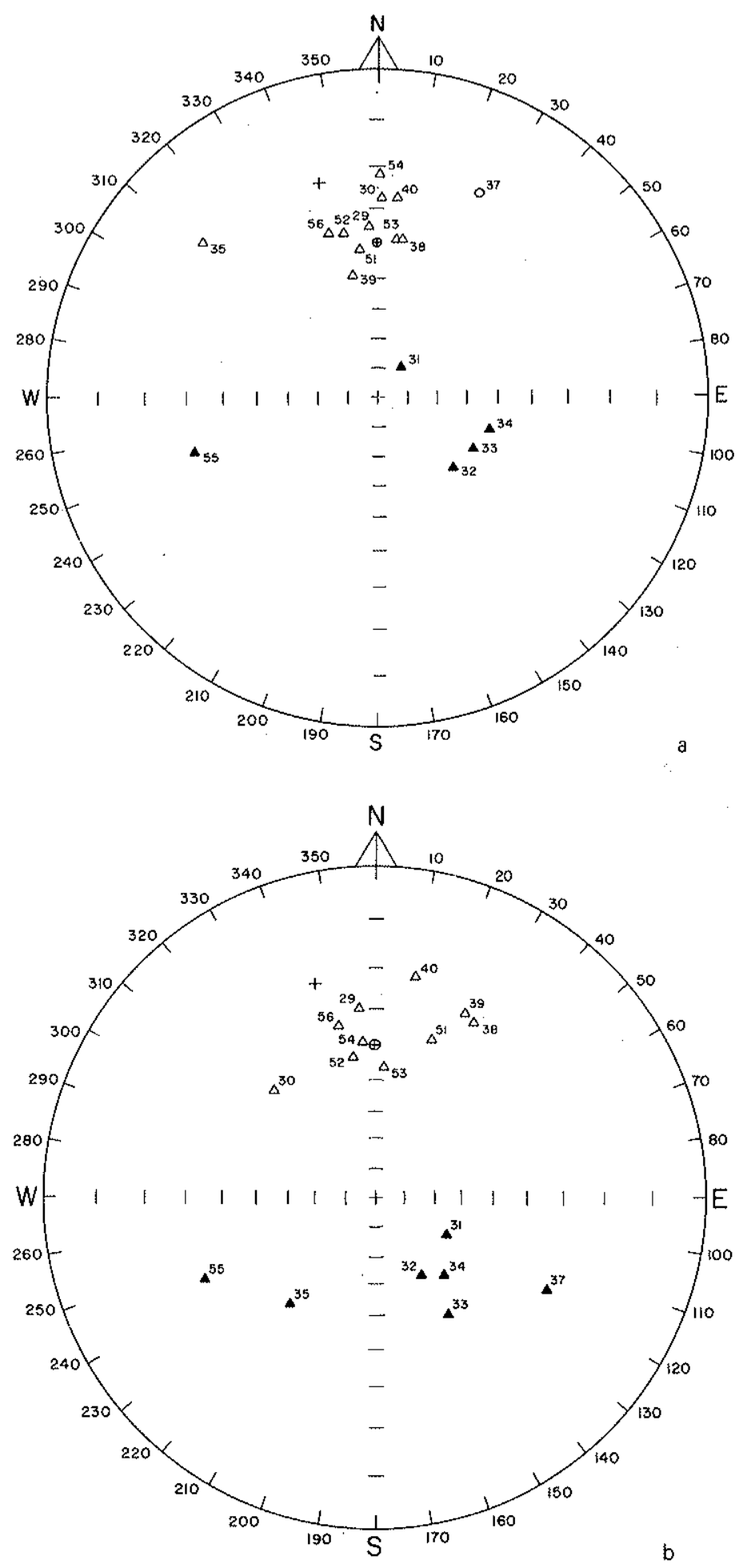

Figure 2 - Directions of n.r.m (a) and cleaned remanent magnetization (b) of hand samples of the Corumbataí Formation, Paraná Basin, Brazil. Solid symbols indicate downward dipping magnetization. Present geomagnetic field in sampling area shown by cross; direction of present dipolar geomagnetic field shown by cross inside circle 


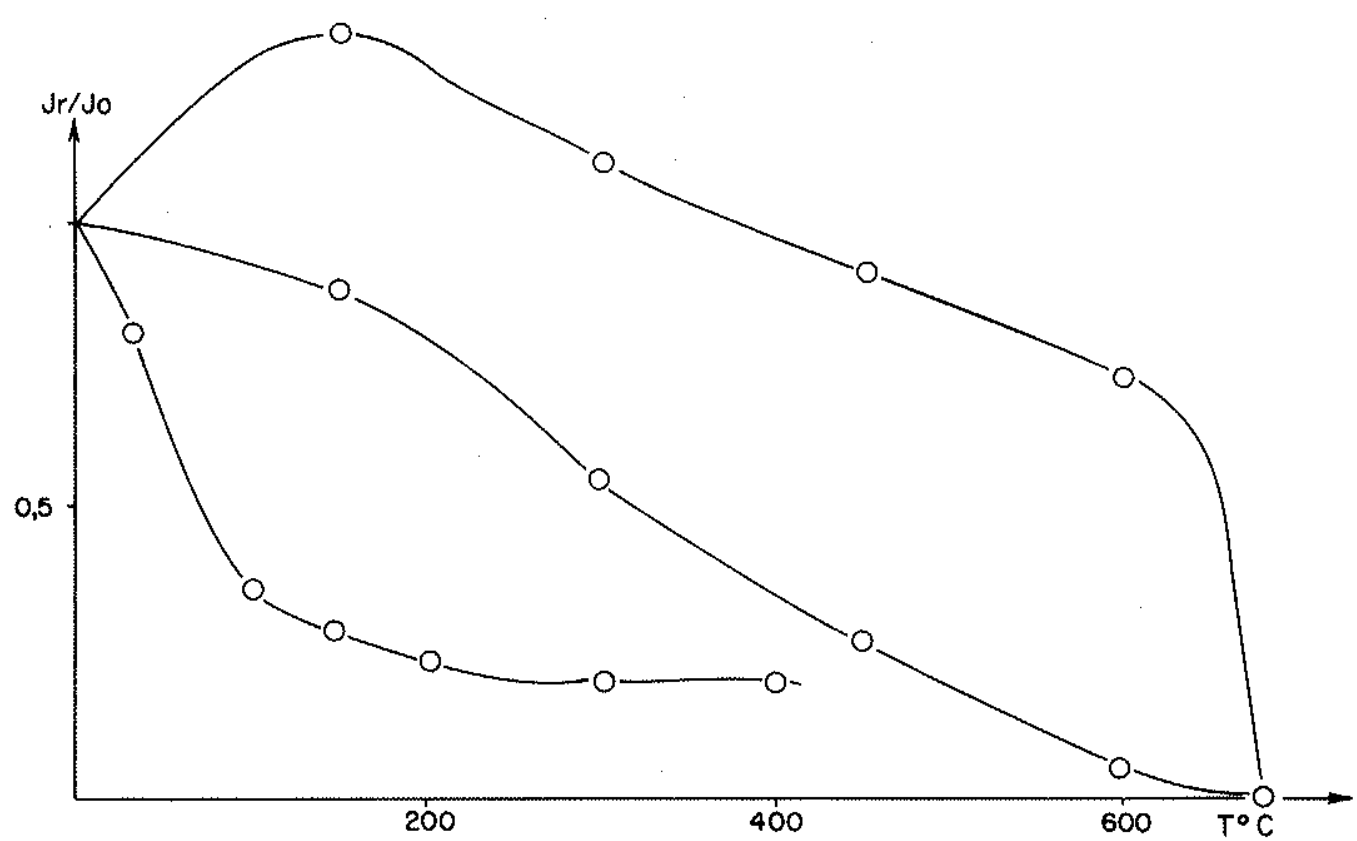

Figure 3 - Thermal demagnetization curves of representative samples from the Corumbatai Formation

versed with respect to the present geomagnetic field direction. The other ten samples yield mean directions toward the north with negative inclinations. The occurrence of well grouped directions divergent from the present field, and the presence of reversed magnetization indicate that substantial secondary remanences are absent. The inexact opposition of reversed and normal sample directions could be due to small secondary components (in which case we could deduce the direction of the larger primary one by forming a population comprising the normal directions, as they stand together, with the reversed directions turned $180^{\circ}$ ). Since the samples have been collected at different stratigraphic positions (see Paleomagnetic Study) they probably keep a record of the geomagnetic field at different moments within the geologic time, which could also explain the inexact opposition of reversed and normal sample directions. This explanation is preferred to the one given above.

In Table I the hand samples from the Corumbataí Formation are ordered according with their stratigraphic positions; therefore, each line represents and independent geological time. Virtual geomagnetic poles for each one of these stratigraphic positions are given in the Table.

Unfortunately, the samples collected from the base of the Corumbatai Formation were lost after the field trip. At least three reversals of the geomagnetic field have been found in samples from the middle and high sections of the Corumbatai Formation (Table I).

Fisher's statistics (1953) was used to compute the mean polar position for the Corumbatai Formation ( $\mathrm{SAP}_{10}$, Table I) giving unit weight to the position of the virtual geomagnetic poles computed for each stratigraphic position of this formation. This mean polar position does not include the positions of the virtual geomagnetic poles computed for the samples numbered 31 and 37, on account of the large values of their parameters of confidence $\mathrm{d}$ and dX. Fig. 6 shows the position of the paleomagnetic pole for the Corumbatai Formation $\left(\mathrm{SAP}_{10}\right)$ in a stereographic projection wich includes South America. 

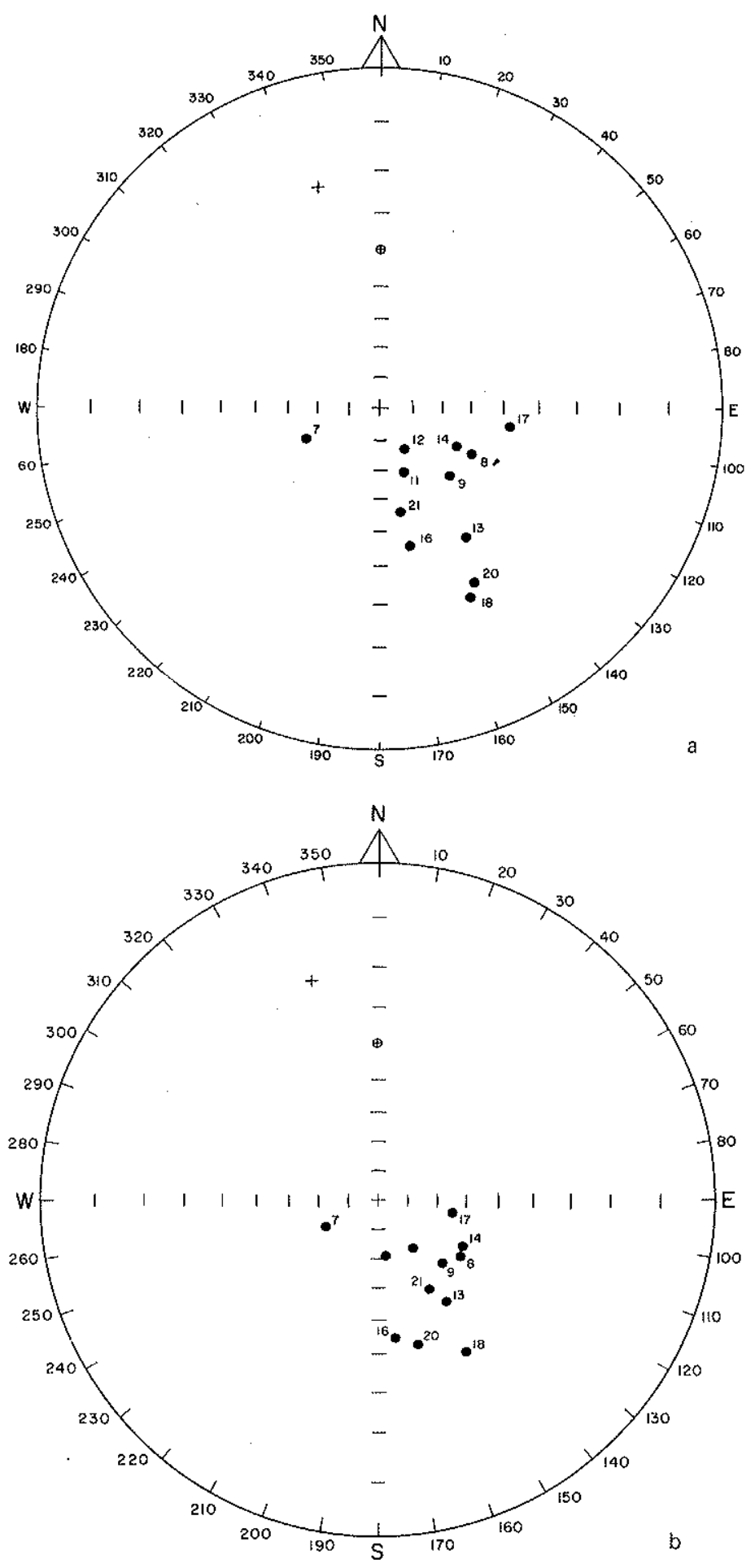

Figure 4 - Directions of n.r.m (a) and cleaned remanent magnetization (b) of sediments of the Itararé Subgroup, Paraná Basin, Brazil. Symbols as in Fig. 2 
ITARARE SUBGROUP The mean directions of natural remanent magnetization of each hand sample from the Itararé Subgroup are shown in Fig. $4 \mathrm{a}$; all these samples have reversed natural remanence. Directions of the natural remanent magnetization of the Itararé samples are fairly well grouped. Thermal demagnetization curves of representative samples from the Itarare Subgroup are shown in Fig. 5. It can be seen by the shapes of these curves that substantial secondary remanences oriented in the direction of a normal polarity field are absent. The samples have blocking temperatures ranging from about $600^{\circ} \mathrm{C}$ to $675^{\circ} \mathrm{C}$.

The best demagnetization temperature for the samples from the Itarare Subgroup oscilates between $200^{\circ} \mathrm{C}$ and $300^{\circ} \mathrm{C}$. Most of the samples keep more than 0.8 of their natural remanent magnetization $(\mathrm{Jr} / \mathrm{Jo} \geq 0.8)$ after the thermal demagnetization to the best demagnetization temperature.

The mean directions of magnetization for each sample from the Itarare Subgroup after thermal cleaning and bedding plane correction are given in Table $I$ and plotted in Fig. $4 \mathrm{~b}$. Directions of the remanence of these samples are better grouped after thermal cleaning (Fig. 4b) than before (Fig. 4a). All the samples yield mean directions toward the south with downward inclinations; obviously these samples are reversed with respect to the present geomagnetic field direction. The occurrence of well grouped directions, divergent from the present geomagnetic field, the presence of reversed remanence and the shapes of the thermal demagnetization curves indicate that substantial secondary remanences are absent.

In Table $I$ the hand samples from the Itarare Subgroup are ordered according with their stratigraphic positions; virtual geomagnetic poles for each one of these stratigraphic positions are given in the Table. Fisher's statistics (1953) was used to compute the mean polar position for the Itararé Subgroup $\left(\mathrm{SAC}_{3}\right)$, giving unit weight to the positions of their virtual geomagnetic poles (Table I). Fig. 6 shows the position of $\mathrm{SAC}_{3}$.

DISCUSSION Fig. 6 shows the Late Paleozoic geomagnetic poles for South America which satisfy a minimum criterium of reliability and the fairly well known Upper Paleozoic

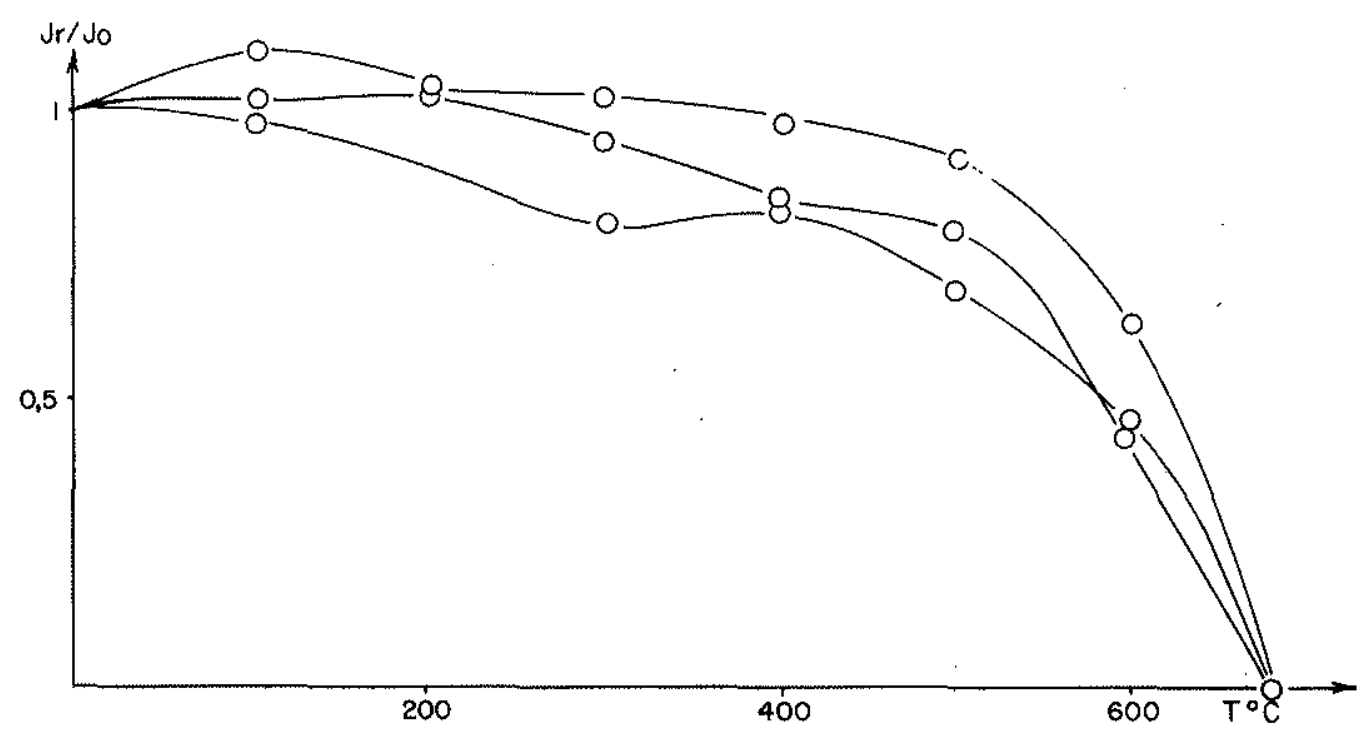

Figure 5 - Thermal cleaning curves of representative samples from the Itarare Subgroup 


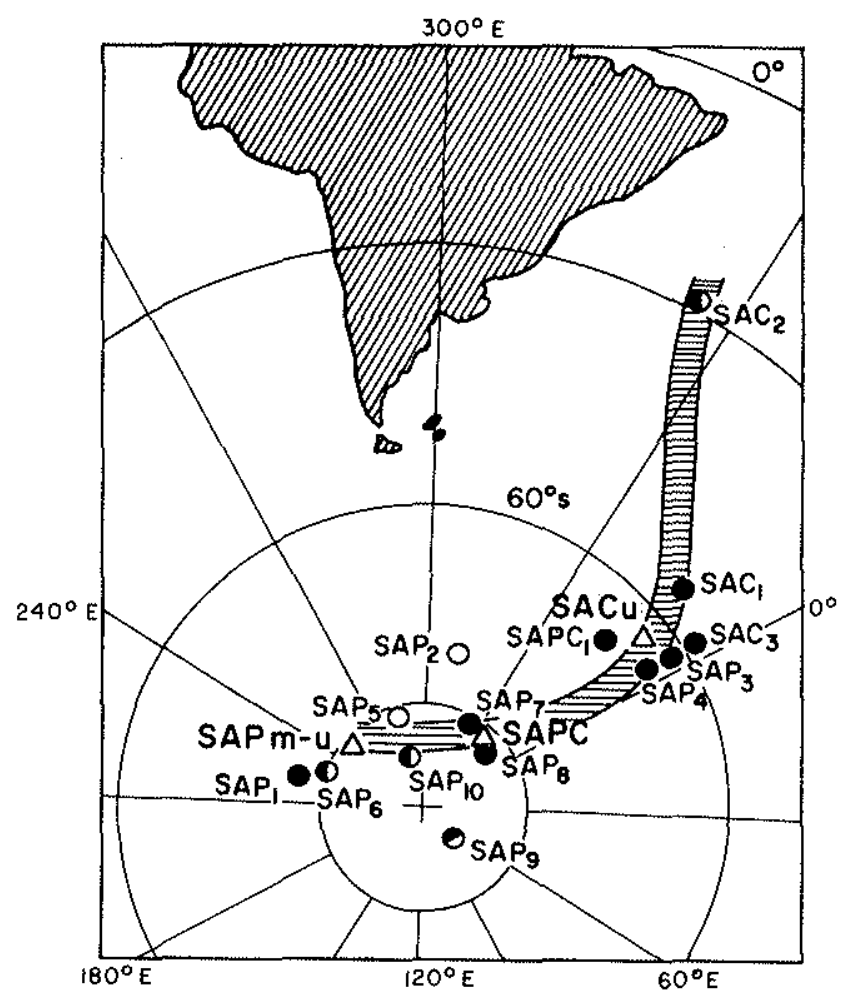

Figure 6 - Late Paleozoic paleomagnetic poles for South America. $\mathrm{SAC}_{3}$ is the paleomagnetic pole for the Itararé Subgroup exposures from Mococa and $\mathrm{SAP}_{10}$ is the paleomagnetic pole for the Corumbataí Formation exposures from the Artemis-Piracicaba area, Brazil. The other paleomagnetic poles are named as in Valencio (in press)

section of the polar wandering curve for this continent (Valencio, in press). The mean polar positions for the Itarare Subgroup $\left(\mathrm{SAC}_{3}\right)$ and the Corumbataí Formation $\left(\mathrm{SAP}_{10}\right)$ are also shown in this Figure.

The polar position for the Itarare Subgroup $\left(\mathrm{SAC}_{3}\right)$ is close to that of the paleomag. netic pole for the Upper Carboniferous Piaui Formation $\left(\mathrm{SAC}_{1}\right)$ and to the positions of the paleomagnetic poles for La Colina Formation exposures $\left(\mathrm{SAP}_{4}\right.$, Huaco and $\mathrm{SAP}_{3}$, Los Colorados) and for the Paganzo Group $\left(\mathrm{SAPC}_{1}\right)$, for which an Upper Carboniferous age has been suggested (Valencio, 1972). This would suggest an Upper Carboniferous age for the stable magnetic remanence or the Itarare samples collected in the Mococa area. All these samples of the Itarare Subgroup have shown reversed stable magnetic remanences. On the basis of the geological data and the polarity of its stable magnetic remanence Va. lencio (1972) has suggested a Sakmarian-early Artinskian or a Stephanian age for the Itararé sediments from Mococa. The polar position computed on the basis of the mean direction of the stable magnetic remanences of the Itarare sediments $\left(\mathrm{SAC}_{3}, \mathrm{Fig} .6\right)$ suggests that the present interpretation is the more probable. Therefore, the geological data, the polarity and the mean direction of the cleaned magnetic remanence of the Itararé samples collected in the Mococa area suggest a Stephanian age for them.

The statistical method of Fisher (1953) was used to compute the mean polar position for the five South American geomagnetic poles assigned to the Upper Carboniferous $\left(\mathrm{SAC}_{1}\right.$, $\left.\mathrm{SAPC}_{1}, \mathrm{SAP}_{3}, \mathrm{SAP}_{4}, \mathrm{SAC}_{3}\right): \mathrm{SACu} ; 62^{\circ}$ South, $353^{\circ}$ East, $\alpha_{95}=4^{\circ}$. This mean polar position is shown in Fig. 6.

The mean polar position for the Corumbataí Formation exposures from the Artemis-Piracicaba area ( $\mathrm{SAP}_{10}$, Fig. 6) is close to the positions of the Middle Permian paleomagnetic poles for South America $\left(\mathrm{SAP}_{5}-\mathrm{SAP}_{6}\right)$ and to the position of the paleomagnetic 
pole for the Upper Permian Pillahuinco Group $\left(\mathrm{SAP}_{1}\right)$. However, to the $95 \%$ level of confidence it is not possible to say whether the position of $\mathrm{SAP}_{10}$ is independent or not of that of the mean of the Permo-Carboniferous paleomagnetic poles for South America (SAPC, Fig. 6). Therefore, on the basis of its position on the Upper Paleozoic section of the polar wandering curve for South America we are able to say only that the age of the rocks with which the paleomagnetic pole $\mathrm{SAP}_{10}$ was computed is younger than Upper Carboniferous.

The cleaned magnetic remanences of the samples of the Corumbatai Formation collected at the Artemis-Piracicaba area on the basis of which $\mathrm{SAP}_{10}$ was computed define three reversals of the geomagnetic field. On the basis of the geological data and these changes of polarity, Valencio (1972) has suggested for the Corumbatai sediments from the Artemis-Piracicaba area an Upper Tartarian or younger (Lower Triassic) age. The position of $\mathrm{SAP}_{10}$ in the Upper Paleozoic section of the polar wandering curve for South America does not disagree with that interpretation, but does not allow us to improve it. A paleomagnetic study of a larger number of samples would allow to improve the confiability of the polar position for the Corumbataí Formation and therefore to test that interpretation.

If we accept an Upper Tartarian or younger (Lower Triassic) age for the Corumbataí sediments from the Artemis-Piracicaba area, we must accept that to the $95^{\circ}$ level conficence the Middle Permian $\left(\mathrm{SAP}_{5}, \mathrm{SAP}_{6}\right)$, the Upper Permian $\left(\mathrm{SAP}_{1}, \mathrm{SAP}_{10}\right)$ paleomagnetic poles for South America form a time group. The mean polar position of this group (SAPm-Tr) is: $82^{\circ}$ South, $245^{\circ}$ East $\alpha_{95}=7^{\circ}$ (Fig. 6). That suggests a quasi-static period for South America from Middle to Upper Permian-Lower Triassic; within this interval South America would not have had movements larger than $7^{\circ}$.

Acknowlegments The senior author (D. A. V.) wishes to thank the University of São Paulo, Brazil and the University of Buenos Aires, Argentina for financial support and other help which enabled the work described to be carried on. We thank Paulo $\mathrm{R}_{\text {r }}$ dos Santos and Armando $M$. Coimbra for cooperation during field work. This paper is a contribution of the IGCP Project Upper Paleozoic of South America (Proj. Prop. n. 73/1/42)

\section{REFERENCES}

ALMEIDA, F. F. M. de - 1954 - Geologia do Centro Leste Mato Grosso, Bol. Div. Geol. Min., n. 150

DAEMON, R.F. and QUADROS, L. P. - 1970 - Bioestratigrafia do Neopaleozóico da Bacia do Paraná. An. XXIV Congr. Soc. Bras. Geol, pp. 359-412

EVANS, P. R. - 1967 - Upper Carboniferous and Permian palynological stages and their distribution in Eastern Australia, Gondwana Stratigraphy, IUGS Symposium, pp. 41-54

FIGUEIREDO FILHO, P. M. de and FRAKES, L. A. - 1968 - Itararé Subgroup (Tubarão Group) in the Mococa-Casa Branca region São Paulo State, Bol. Soc. Bras, Geol., 17 (1): $59 \cdots 63$

FISHER, R. A. - 1953 - Dispersion on a sphere, Royal Soc. London Proc. Sec. A., 21.7

KEMP, E. - in press - The palynology of Late Paleozoic glacial deposits of Gondwanaland, $3^{\text {rd }}$ International Gondwana Symposium, Canberra, Australia, 1973

LANDIM, P. M. B. - 1970 - Contribuição ao conhecimento dos mistitos do Estado de São Paulo, L. Doc. Thesis, Fac. Fil. Ciên. Letras de Rio Claro, Rio Claro, SP

ROCHA-CAMPOS, A. C. - 1967 - The Tubarão Group in the Brazilian portion of the Parana Basin, in J. J. Bigarella, I. D. Pinto and R. D. Becker (Eds.), Problems in Brazilian Gondwana Geology, Guritiba, Brazil, pp. 27-102

ROCHA-CAMPOS, A. G. - 1973 - Megafossil evidence on the age of the South America Gondwana glacial deposits, Abstracts, $3^{\text {rd }}$ International Gondwana Symposium, Canberra, Australia 
VALENCIO, D. A. - 1972 - Intercontinental correlation of Late Paleozoic South American rocks on the basis of their magnetic remanences, An. Acad. Bras. Ciên., 44 (Suplemento): 357-364

VALENCIO, D. A. - in press - The South American paleomagnetic data and the main episodes of the fragmentation of Gondwana, Geodynamics on the Eastern Pacific Region and Related areas Symposium, Lima, Peru, agosto, 1973

VALENCIO, D. A. and MITCHELL, J. - 1972 - Paleomagnetism and K-Ar ages of Permo-Triassic igneous rocks from Argentina and the intercontinental correlation of Upper Paleozoic Lower Mesozoic formations, 24th International Geological Congress, Montreal, Canada, Section 3, pp. $189-195$ 